\title{
The Transnationalization of Labor Mobility: Development Trends and Selected Challenges Involved in Its Regulation
}

\author{
Ludger Pries $^{1} \&$ Martina Maletzky ${ }^{1}$ \\ ${ }^{1}$ Fakultät für Sozialwissenschaft, Lehrstuhl Soziologie, Ruhr-Universität Bochum, Bochum, Germany \\ Correspondence: Ludger Pries, Fakultät für Sozialwissenschaft, Lehrstuhl Soziologie/SOZOMM, \\ Ruhr-Universität Bochum, 44780 Bochum, NRW, Germany. Tel: 49-234-32-25429. E-mail: \\ ludger.pries@rub.de
}

Received: February 13, 2017

Accepted: February 27, 2017

Online Published: April 9, 2017

doi:10.5539/res.v9n2p115

URL: http://doi.org/10.5539/res.v9n2p115

\begin{abstract}
Internationalization of value chains and of for-profit as well as non-profit organizations, and as a result of cheaper and safer mass migration, transnational labor mobility is of increasing importance. The article presents the development of the different types of cross-border labor mobility (from long-term labor migration over expatriats/inpatriats up to business traveling); it analyses crucial aspects of labor conditions and how the collective regulation of working, employment and participation conditions in general is affected: could local or national forms of labor regulation cope with these new conditions? What are the main challenges when it comes to collective bargaining and the monitoring of labor conditions? The article is based on a three year international and comparative research in Germany and Mexico. First, different ideal types of transnational labor mobility are distinguished that have emerged as a result of increasing cross-border labor mobility. Then potential sources of labor related social inequality and challenges in the regulation of the working, employment and participation conditions for transnational workers are discussed. Finally, some conclusions are drawn for further research.
\end{abstract}

Keywords: transnational labor mobility, expats/inpats, labor migration, labor regulation, Germany, Mexico

\section{Introduction}

Cross-border labor mobility is as old as mankind. But from the early development of the industrial mode of production until the end of the 20th century gainful employment was to a large extent structured by mobility spaces that were defined by regional or, at most, national boundaries. In most cases, getting to work involved commuting on a daily basis, and only small groups of technical experts and construction workers ever travelled long distances to get to their workplaces. For centuries, people have been travelling long geographic distances between the actual center of their lives and places in which to perform additional seasonal work, but these individuals represented only a fairly small segment of the working population. Activities that involve continuous mobility have existed for over a millennium in the form of long-distance trade, but in the past this occupation focused primarily on luxury goods and provided work for relatively few mobile individuals compared with non-mobile workers.

With the internationalization of value chains and performance organizations, and as a result of relatively cheaper and safer mass migration movements, this picture has changed fundamentally. For an ever-increasing percentage of the working population, labor mobility is becoming transnational in the general sense of crossing national and cultural boundaries. This is true not only of individuals who migrate within Europe to find work in other countries because they cannot find any in their own due to the recent economic downturn, but also of contractors and subcontractors and of employees of for-profit and not-for-profit organizations, whose work is increasingly characterized by cross-border mobility. Given the growing number of individuals from a wide variety of different cultures and countries who are living in many places around the world, international organizations find it increasingly easy to recruit employees with intercultural experience and skills in the language of the headquarters and hire them on the local terms and conditions of employment. This leads to social inequality between the mobile workers, such as between individuals who are posted by their organization and those who migrate on their own initiative, and between workers who are posted to a peripheral subsidiary by their organization's headquarters and those who are ordered to leave their workplace in the "periphery" and work at a central subsidiary of a transnational organization. 
How do these increasingly transnational forms of labor mobility influence the established forms of the collective regulation of working, employment and participation conditions? What challenges do they bring? Are local or national forms of labor regulation even still appropriate and effective? What are the main challenges when it comes to collective bargaining and the monitoring of labor conditions? These questions are explored in the following sections. It begins with proposing different ideal types of transnational labor mobility that have emerged as a result of increasing cross-border labor mobility (Section 1), and to discuss potential sources of inequality and challenges in the regulation of the working, employment and participation conditions for transnational workers (Section 2). In the final section (Section 3), some conclusions will be drawn for further research.

\section{Types of Transnational Labor Mobility}

Economic, political, cultural and social globalization and transnationalization, especially of organizations (Pries, 2008), cause that employment conditions and labor-related events in one specific place can have effects on regions and national societies in completely different and far-away parts of the world. Simultaneously, forms of transnational labor migration become increasingly widespread, resulting in cross-border migration as becoming a regular part of the employment histories of an ever-growing number of people. For a smaller segment of the population, even maintaining a clear local or national identity becomes increasingly difficult. For a growing number of individuals, migration no longer involves only two geographic points (the regions of origin and arrival) and one or two points in time (the time of emigration and return migration). Frequent migration movements are becoming part of transnational migrants' life courses, which can still be continuous. The everyday lives, employment expectations, career paths, budgetary strategies and biographical orientations of a growing number of (labor) migrants are no longer rooted in only one local community or one national society. Rather, social practices, symbolic systems and artifact structures lead to the creation of ever-denser networks of transnational social relationships, which form new transnational social spaces that span across multiple locations in different national societies. Recently, there has been research on such transnational labor migration networks and social spaces in North America (e.g., Besserer, 2002; Smith, 2005) and in Europe (Pallaske, 2001; Pries, 2001). Given the general trend towards internationalization and socialization, they will be of increasing importance in the future; generally speaking, the lines between migration and other forms of geographic mobility are becoming increasingly blurred. The lines between individual and organized labor mobility are blurred; for example, employees who are sent to another country by their organization, may make the individual decision to stay in that other country permanently, or individuals, who have migrated to another country on their own initiative, can take up employment in that country with an organization, which may then require them to engage in organizational transnational labor mobility.

Thus, transnational labor mobility encompasses several types of migration, chief among which are the traditional forms of individual (labor) migration in the sense of individuals moving to another society and establishing their home there, as was typical of a certain segment of the "guest worker" population in Germany. Four groups of individual (labor) migrants can be distinguished: (1) emigrants/immigrants (migrants who gradually adapt their identity and their life world to assimilate into their country of arrival); (2) remigrants (individuals who leave their country of origin for a limited period of time with the intention of returning at some point); (3) diaspora migrants (migrants who have migrated for religious or organizational reasons and do not assimilate fully into their country of arrival); and (4) transmigrants (individuals who engage in alternative forms of migration, such as repeat and multi-directional circular migration). The latter group is an ideal type of migrants whose life praxis and life projects create social spaces which span locations in different countries.

Organized labor mobility, on the other hand, is mobility that is induced by an organization. Depending on the perspective one takes, individuals who engage in this form of mobility are referred to as (1) expatriates (employees whom the head office sends to an overseas subsidiary on a long-term assignment); (2) posted workers (workers whom an organization in a European country sends overseas on a short-term assignment to perform [service] work); (3) inpatriates (employees from an overseas subsidiary who come to the head office, usually to learn about processes and concepts); and (4) third-country nationals (employees who are sent between two overseas subsidiaries. Another group are (5) commuting assignees, that is, employees who are at home and are rooted in two locations. In addition, there are (6) frequent business travelers. These employees are here today, there tomorrow, but they usually perform the work of their home office and they still have a localized home base, unlike the commuting assignees, who have multi-local and multi-national affiliations and are confronted with different working conditions whenever they are sent on a new assignment.

Organized mobility in particular has become increasingly important over the last few years. According to the German Business Travel Association, in 2013 there were 171.1 million national and international business 
travels in Germany (Verband Deutsches Reisemanagementee.V. [VDR], 2014). Individual employees in Germany have also been subject to processes of rationalization and normalization (Kesselring, 2012; VDR, 2014), with the result that employees are increasingly expected to be mobile, and that compensation and benefits are now lower than in years past, while the job requirements they have to meet are becoming ever more demanding. There has also been a growing number of employees of companies that operate internationally who relocate for long periods of time. It is expected that in many companies the number of such employees will continue to grow (Brookfield, 2012a, 2012b; Mercer, 2013), and one study has observed that there has been a trend towards normalization, with compensation packages becoming less and less generous (Adick et al., 2014; FAZ, 2010; Brookfield, 2012a). For years, this development has been affecting not only high-level employees in multi-national corporations but also a growing number of lower-level employees in small and medium enterprises (Schmierl, 2011).

The number of posted workers has also been growing steadily, although reliable figures are difficult to obtain (Staples et al., 2013). Since the 1990s, workers coming to Germany have been posted on the basis of bilateral agreements, most notably with countries in Central and Eastern Europe and with Turkey. Most of these workers were posted in the mid-1990s. In the wake of the financial crisis, the number of newly posted workers was drastically reduced, at first only in a few sectors (construction, cleaning, domestic work) but, starting in 2004, also in other industries, such as meat packing (Cremers et al., 2007). This variety of different forms of mobility represents a potential source of inequality, which in the past has often been neglected as a subject of labor regulation and which presents challenges for labor regulation that increase exponentially due to the transnational dimension (see Table 1).

Table 1. Types and characteristics of individual and organized labor mobility

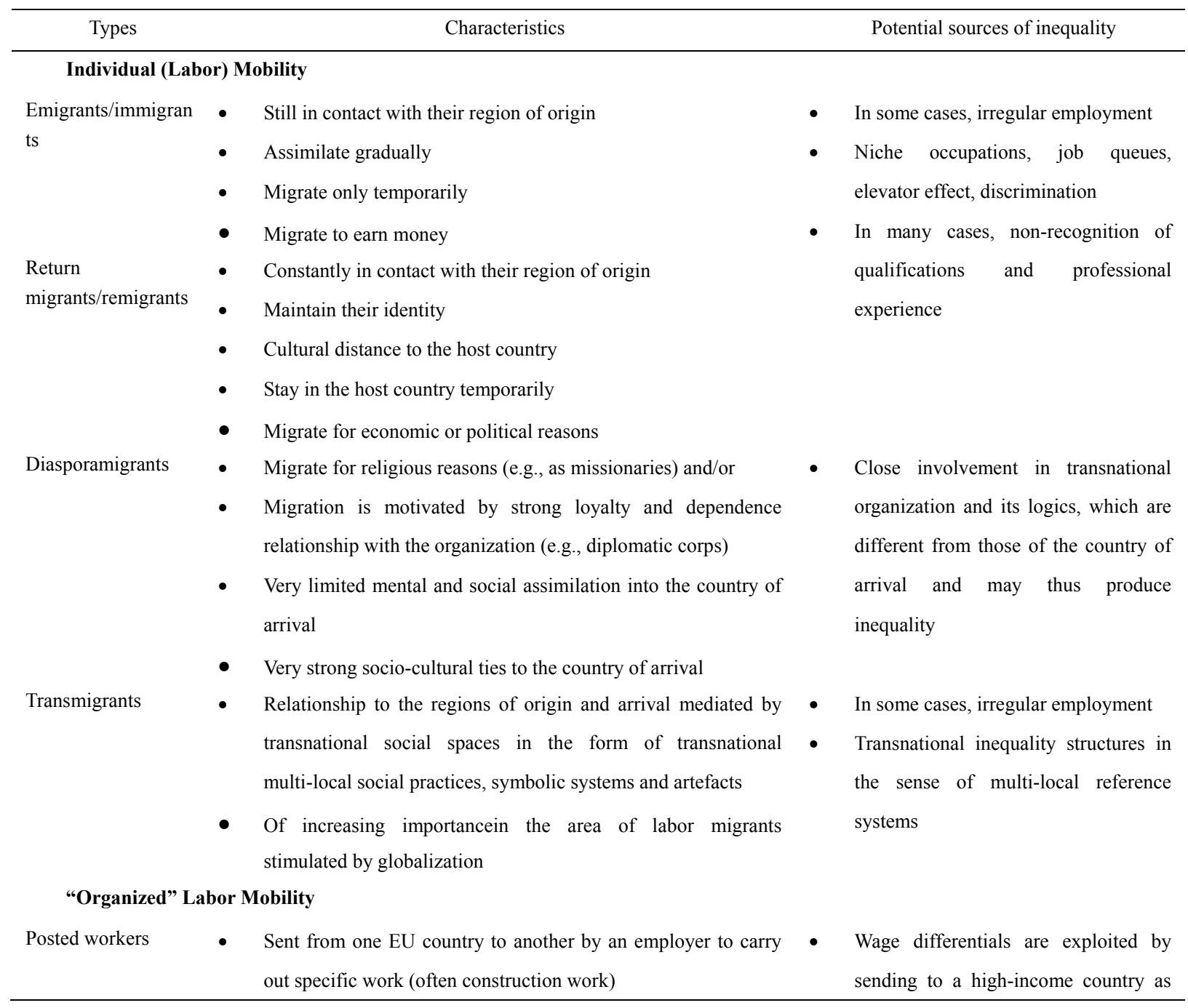




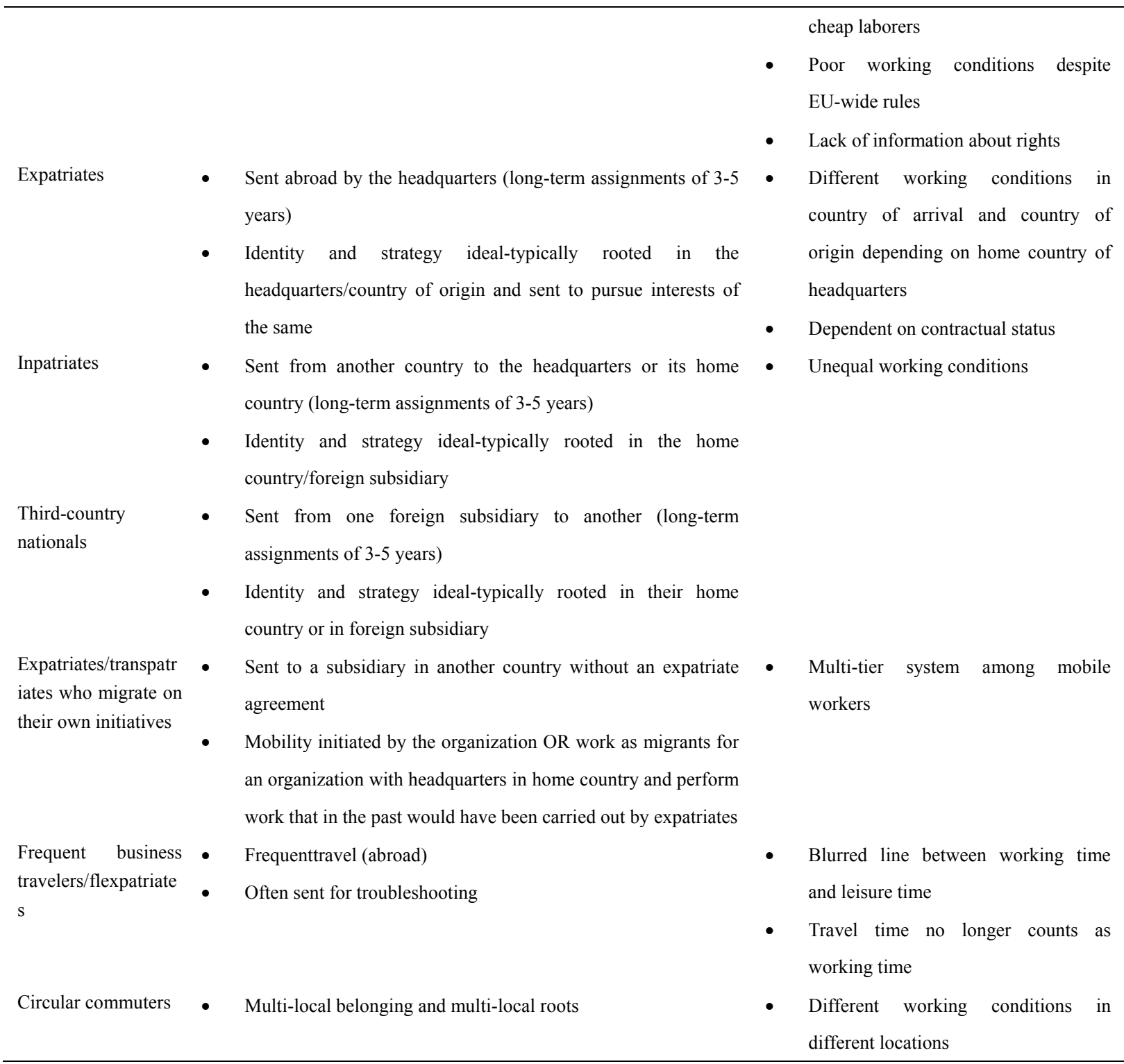

Immigrants and remigrants are faced with discrimination and declining opportunities in the labor markets (Nohl et al., 2010a; Kogan, 2011). In extreme cases, this results in the emergence of sources of inequality between these migrants and the members of the society of arrival, such as when irregular employment opens the door for discrimination, the development of intricate dependence structures and threats by employers (see, e.g., Shinozaki, 2013; Schönwälder et al., 2004). Many migrants are forced into precarious work in certain niches in the labor market (on domestic work, see, e.g., Moha, 2007), not least because their qualifications are not recognized at all or only after a very long delay (see, e.g., Neumann, 2010; Constant \& Massey, 2003). According to the labor queuing theory developed by Reskin (1991), there is a shortage of workers in these niche areas of employment because of the unattractiveness of these jobs. The German labor market in particular is characterized by a sharp distinction between insiders and outsiders (Kogan, 2011) that creates a climate in which migrants often experience discrimination (Neumann, 2010). Because access to the labor market is difficult, work within social networks is done by migrants, who follow their own logics of justice and participation; often these logics are based on those prevalent in the migrants' country of origin and associated with low pay (Schmidtke, 2010).

Many migrants who take up such jobs are forced to work under worse working conditions than German employees, and their niche jobs are commonly associated with "migrant worker" (Nohl et al., 2010b). In many cases, this leads to "elevator effects", meaning that non-migrant employees are elevated to a higher social level by the fact alone that other groups - in this case, the migrants - are forced to accept work and employment conditions at the lower end of the social hierarchy. Studies have also shown that migrants display less labor 
mobility than non-migrant employees do (see Constant \& Massey, 2003 on guest workers; Schittenhelm \& Hatzidimitriadou, 2010 on highly qualified migrants). However, many actors, especially migrants who strongly identify with their country of origin, view social inequality from a subjective transnational perspective, which causes them to regard working conditions that by the standards of the country of arrival are considered poor as not that bad when compared with the conditions in their country of origin. As a result, many migrants are prepared to work under conditions non-migrant workers would not be quite so ready to accept (Bade, 2003, pp. 229-231). This in turn leads to the production or reproduction of encrusted structures of social inequality. But for migration to be just, migrants need opportunities for equal participation in their country of arrival.

Diaspora migrantsare closely involved in their transnational organization and its logics; these logics are different from those in the country of arrival and therefore may be a potential source of inequality (Salustowicz, 2009). For example, when employees from the home country of a diaspora organization work with local employees, the differences between their working conditions and their logics can lead to conflicts that are similar to those observed for organized mobility. Like migration and remigration (see above), diaspora migration is likely to lead to the formation of ethnic niches and, depending on the status on the members of the diaspora, to either positive or negative queuing.

Organized labor mobility is influenced even more by a transnationalization of the working conditions and of the structures of social inequality that affect the lives of migrants than individual labor migration, which is taken as a long-term strategy. This is because in the country to which they are sent, actors who engage in cross-border mobility work in direct contact with co-workers who are on the same hierarchy level and in the same functional group as they are, but whose working conditions are significantly different from their own. This creates a situation of competition that might prove difficult for organizations and their employees (Hailey, 1996), and that might affect the motivation of local employees who feel that they are paid and treated less well than their transnationally mobile peers (see, e.g., Chao et al., 2002; Konopaske \& Werner, 2002). However, the degree of transnational inequality varies depending on the countries involved and on the (collectively bargained) employment conditions for posted workers. Inpatriates and third-country nationals who are sent from a low-cost country to the country in which the organization's headquarters is located usually find themselves in a better financial situation compared with the situation in their country of arrival-with the result that, if anything, it is more of a challenge for them to again get used to the wage structure of their home country after their return. Most companies pay their expatriates according to the wage structure of the employees' country of origin (KPMG, 2012, p. 31), although this can still put employees at a disadvantage, such as when employees who are working in another time zone are expected to work overtime because of the time difference, or when they are expected to use work practices that are not managed appropriately by using a transparent time account system. Intransnational organizations with a pronounced center-periphery structure, actors from the periphery might also be stigmatized or discriminated against; after all, such behavior would reflect the dominant transnational status structure and social structure within the organization (Harvey et al., 2005). In addition, employees from the periphery are often seen as competitors. They often have inadequate information about individual and collective rights and about the relevant labor law provisions (which also means that they are more likely to be prepared to make concessions). Generally speaking, international mobility appears to have been normalizing recently (Adick et al., 2014), with special privileges and employee benefits being reduced and international mobility no longer being regarded as something that merits additional compensation (Brookfield, 2014). The more the transnationalization of life worlds progresses, the more individuals everywhere are prepared to be mobile. The fact that an increasing number of employees are now expected to be mobile also confirms many people - especially young employees and jobseekers - in the belief that to have a career, one must go abroad and be prepared to forgo privileged working and employment conditions (Adick et al., 2014). In many cases, mobility is organized without according employees special expatriate status, which depending on the countries involved may leave them at a disadvantage. This is particularly true of employees who are mobile within the same geographic region (Europe, North America). One of the more recent trends in this area is what has been referred to as "local-plus compensation" for expatriate employees (Brookfield, 2012b; AIRINC, 2011). A cost-saving alternative are locally hired foreign employees from the organizations' home country, some of whom also receive compensation under local-plus agreements, which is just slightly above the host country average (on the situation in Asia, see Mercer, 2011).

Being posted abroad also brings with it multiple forms of inequality, not least for the employees' partners who travel with them, most of whom are women. Because they find it difficult to access the labor market in the foreign country, many of them are forced to stop working altogether for the time of their partner's assignment abroad, which might affect their own career prospects. Some steps have already been taken to address the 
dual-career issue, especially in large corporations, but in most companies, the management of mobility continues to be based on traditional views of gender roles and family structures and on the assumption that an expatriate is a male employee who travels with his wife, who is primarily responsible for the reproduction of the family. Companies' mobility regimes thus reflect the structure of hegemonic masculinity. Some companies have special programs to support their travelling employees' marriage partners in finding employment in the country of assignment (KPMG, 2010), but very often these programs are prescriptive in that they are geared towards male employees with an accompanying female partner. According to the Global Assignment Policies and Practices Survey, only about $20 \%$ of the companies surveyed help female partners find employment; about the same percentage pay for further training and education; and only $14 \%$ paid the work visa fees for the partners who went abroad with the companies' employees (KPMG, 2010). The Brook field Global Relocation Services' 2012 Survey Report on Global Relocation Trends, which is based on a sample of companies from a variety of different countries, found that $49 \%$ of the partners who went abroad with the companies' employees were employed before the start of the assignment, but only 6\% were still employed during the assignment (Brookfield, 2012, p. 32 ). It seems reasonable to assume that these figures would be even more pronounced for German companies and their employees: Kupka and Cathro (2007) note that German companies display particularly little sensitivity to the needs of the partners of employees who are sent abroad on assignments (Note 1). One study has found that while abroad, female partners take on responsibilities, sometimes as part of dual career programs, which are not directly related to furthering their own professional career, such as when a company's dual career program also includes club memberships (KPMG, 2010).

When we look at business travel, the general trend towards a normalization of mobility becomes even more apparent than in the case of worker posting. The line between working time and leisure time is becoming increasingly blurred. In the past going on a business trip was a privilege - today it is a perfectly normal part of work that merits no special recognition (Kesselring, 2012, p. 88). In many companies, travel time no longer counts as working time, and business trips are becoming shorter and less comfortable (Kesselring, 2012, p. 88; Adick et al., 2014). Companies regard business travel as an important area for cost saving and seek to make the conditions for, and the management of, mobility more efficient. Organizations do not necessarily reduce the volume of business travel in times of financial difficulty, but they consider business trips as an item in the budget that allows them to save considerable amounts of resources. By establishing organizational barriers (application procedures, expense reporting, department- or project-related cost application), lowering standards (economy class instead of business class, hotel downgrading, limited expense accounts) and relying increasingly on virtual communication, organizations are trying to make business trips less attractive and reduce the volume of business travel (Adick et al., 2014). But this comes at the expense of those who have no choice but to travel. The blurring of the line between working time and leisure time (as when employees are expected to be on call twenty-four hours a day, seven days a week) and activities that are tied to a particular location are features of everyday practice that are structured by the organizations' mobility regimes (Kesselring, 2012).

Posted workers are a hybrid of expatriates and circular migrants (Staples et al., 2013). The members of this group are hired by a service provider that is located in a poorer EU country and sent on short-time assignments in various different locations in richer EU countries, usually in occupations that do not require a high level of qualification, such as meat packing, working on large building sites or seasonal harvest work. The commissioning and the contracting firms involved systematically exploit the wage differentials between the EU countries. The majority of posted workers are marginalized in the society of arrival and experience isolation, a precarious residence status and discrimination (Staples et al., 2013). The fact that posted workers are paid according to the wage structure of their home country has often led to demands for minimum wages in the past. For example, Cremer (2007) reports questionable practices of employers in this area, many of whom do not pay posted workers according to their qualifications and working hours, with unpaid overtime often being the rule rather than the exception. Many posted workers are officially hired and paid to work 40 hours a week, but actually work 60 hours and have little free time to rest. In many cases, companies which hire posted workers do not comply with health and safety regulations and do not provide their workers with information about safety measures. Employers have also been known to charge too much for the accommodation they offer, and the fact that posted workers labor under poor working conditions is not an insignificant factor in strengthening the position of employers in negotiations with their own local employees, which can lead to a general decline of working standards (on the situation in Finland, see Lillie, 2012). 


\section{Challenges for Collective Labor Regulation}

Labor migration as a subject of labor regulation has always been a contested terrain between employers' associations and trade unions. Whereas companies and their trade associations are usually in favor of high levels of labor immigration, many trade unions are concerned that immigration might lead to increasing competition among employees, lower wages and declining working conditions, because most labor migrants come from countries where the rights of workers are not protected as well as in Germany. There has been extensive research on the challenges that individual international migration presents for collective labor regulation (see, e.g., Penninx \& Roosblad, 2006).

However, there is very little in the literature of the social sciences on organization-related cross-border mobility, and even less research has been done to address the relevant questions concerning the collective regulation of working, employment and participation conditions in sufficient detail. Cross-border mobility is also neglected as a subject of co-determination in organizations (Schmierl, 2011). Given the spread and diversity of cross-border mobility outlined above, there is little to justify the neglect of the subject any longer. Individual and organizational cross-border labor mobility is affecting an ever-growing group of individuals. It is no longer just limited to certain expatriate elites within companies, who are widely assumed to be offered generous working and employment conditions anyway. Organizational transnational labor mobility is affecting an ever larger group of employees from across all hierarchy levels of small, medium and large enterprises (Schmierl, 2011) and international not-for-profit organizations. Of the last-mentioned type of organization regarding the percentage of local and internationally mobile employees, more employees work abroad as mobile employees than in POs (Brewster \& Lee, 2006), and their working and employment conditions are often even more precarious than those of company employees (Maletzky \& Weiler, 2013). From this, we can derive a number of specific topics related to the regulation of transnational labor mobility.

Migration presents a variety of different challenges depending on the type of migration under study. Permanent immigration that also involves the granting of full citizen rights allows trade unions to integrate the immigrants into existing working cultures. However, the question both the employing organizations and the trade unions which represent the interests of the mobile employees have to ask themselves is whether specifically targeted programs - for example, programs to manage diversity or promote intercultural skills - are actually needed, and if so, how to demand that such programs be implemented. The policies of many trade unions has been based on an assimilationist understanding of migration and integration processes, according to which immigrants gradually assimilate into society more or less automatically, so specific diversity and intercultural-awareness programs would not be necessary. It is also often argued that such activities are costly and time-consuming, and that they might actually further entrench rather than reconcile divergent views on work, employment and trade unions. However, because they are bound to the principle of international solidarity and because they must maintain credibility, both internally and externally, trade unions must give special attention to labor migrants, who are usually in a weaker position in the employment system (Examples in Germany include the "Faire Mobilität" and "MigrAr" initiatives of the Confederation of German Trade Unions) (Note 2). Providing support for refugees and asylum seekers also poses a challenge, not only because of the humanitarian needs of these migrants but also because those among them who do not have a work permit might be forced to take up irregular work, which in turn can lead to a decline of existing employment standards.

The same effect occurs if organizations systematically exploit wage differentials within the EU, a practice that often leads to precarious working conditions for posted workers despite EU-wide regulations (Note 3). This is due to a lack of information and alternatives for the employees and to loopholes that undermine the implementation of the regulation on the national levels (cf., Staples et al., 2013; on the situation in Finland, see Lillie, 2012). "Worker posting facilitates the undermining of national industrial relations systems through the introduction of alternative firm practices and regulatory regimes into spaces where they are foreign, fueling direct competition between (national) groups of workers" (Lillie, 2012, p. 148). Posted workers are in a less favorable position than migrants, who are at least formally subject to the labor standards of the country of arrival and who have a right to equal treatment. The European Court of Justice allows companies to create what could be called a space of exception between the Europe-wide and the national regulations to give the working relationships of transnational sub-contractors an extraterritorial character (Lillie, 2012, p. 151). This presents a variety of challenges in the implementation of the directives: "As far as the practical application was concerned the Commission identified a number of problems: difficulties to verify whether a genuine employment relationship exists, the failure to monitor compliance, the difficulty in comparing the host country requirements and the working conditions in the country where the worker normally executes the work, and, not least, the lack of access to relevant provisions applicable in the host country" (Cremers et al., 2007, p. 529). 
The same question - of who might be responsible and what collective regulations might serve to prevent, or at least compensate for, discrimination and declining working standards - arises when we look at the other forms of organized mobility. Although transnationally mobile employees belong to a cross-border organization that acts a single entity, they are always actors who, at least temporarily, move within two or more different institutional frameworks that regulate working, employment and participation conditions. Therefore, the question that always presents itself is which criteria to use: those of the host country or those of the migrants' country of origin? The general rule in most organizations is that being sent abroad on an assignment should not have a negative effect on the assignee's working, employment and participation conditions (Adick et al., 2014). However, when it comes to the different types of transnational mobile individuals listed in Table 1 above, there are very different ways of implementing this rule in practice. One reason often given to justify the working and employment conditions for one-year intern or trainee assignments (small salary, no comprehensive benefit packages as for regular expatriates, high expectations regarding performance and initiative) is that applicants go abroad to prove themselves and to learn, and that they will reap the rewards later (Adick et al., 2014; Maletzky \& Weiler, 2013). Most applicants are not explicitly promised that they would have a career in the organization or that they would be considered for future assignments, and if they are, such promises are not always kept.

Many companies also nurture the belief that employees can make a career jump if they are sent abroad on assignments, which motivates employees to improve their performance. However, many of them become frustrated when they realize that the functional areas or the positions in the hierarchies they are offered after their return are not what they had expected, and that the return process is usually not particularly well planned (Schmierl, 2011). The myth of the career jump after an assignment abroad can also be observed in not-for-profit organizations (Maletzky \& Weiler, 2013). Some of them send trainees or assistants on assignments on fixed-term contracts and without any guarantee that they can continue working for the organization after their assignment is over. Many of them have to perform the same highly demanding work as regular expatriates and accept the blurred line between working time and leisure time, but without being accorded the privileges and benefits that would normally come with these positions. This makes this group a cost-saving and flexible replacement for expensive expatriates (Maletzky \& Weiler, 2013).

Until the beginning of the 21 st century, work agreements guaranteed that employees on business travel would receive substantial benefits (removal costs, support in finding new accommodation and compensation for additional costs, arrangements for the family to travel along with employees on short-term assignments, frequent flights home). Today negotiations over individual agreements are often more about making sure that the employees on business travel are not put at a disadvantage (cf. e.g., Adick et al., 2014). To give an example: When inpatriates from a low-cost country are posted to the home country of their organization they are in a better position financially than their co-workers in their country of origin but may still earn less than their co-workers in the country of arrival. This can create tension.

Workers' employment conditions always depend on their contractual status. The principle of freedom of contract ensures that employees and employers are generally free to choose the jurisdiction that will govern the employment agreement between them, provided that the law of the jurisdiction they choose is not in conflict with the law applicable in the employee's place of habitual residence, which protects the employee and which is binding on both parties (Internationale Handels Kammer [IHK], 2014). The country of arrival's statutory regulations on issues such as working-hour limits or health and safety in the workplace apply regardless of the choice of jurisdiction.

With cross-border labor mobility losing its status of being the exclusive privilege of small groups of managers who have decided to forgo the benefits of collectively bargained working, employment and participation conditions because they have other resources at their disposal, the actors involved in labor regulation are dealing with new issues, such as taxation and retirement planning for employees. Another important question is how employees who are posted abroad can achieve a satisfactory work-life balance, considering that many HR departments issue regulations that are impossible to comply with or unrealistic (Shortland \& Cunnings, 2007; Shaffer et al., 2001). Kesselring (2012) notes that issues that are particularly important for commuting assignees and frequent business travelers include the achievement of a satisfactory work-life balance and the consideration of travel time as work time, but also corporate career planning and training, and opportunities to participate actively in the forms of collective labor regulation used within the organization, which latter includes the active and passive right to vote in matters of employee representation and the opportunity to get into direct personal contact with the responsible bodies of interest representation in the first place. It would appear that the old adage "out of sight, out of mind" is also true in most of the cases considered here: employee groups who are not 
present and visible all the time must make strenuous efforts to get into the focus of attention of the HR departments and the bodies of interest representation within their organization.

With transnational mobility increasingly becoming a routine aspect of employees' everyday work life, general sending conditions are being gradually downgraded across the board. This creates a need for more extensive regulation. Faced with growing cost pressures, many organizations have started to turn to alternatives to the costly practice of posting employees abroad and its associated benefits. For HR departments, benefit packages are a major cost element and, for this very reason, an item in the budget that offers enormous cost-saving potential. The normalization of labor mobility Kesselring (2012) and others have observed is accompanied by a minimization of expatriate bonuses and an increase in the number of employees who are sent abroad alone, without their partners (This, incidentally, is the reason why the issue has become a matter of public interest, which has also been taken up by the press; see, e.g., FAZ, 2010). HR departments are now planning to reduce labor costs by hiring more and more local staff on the basis of "local plus" agreements, which are less attractive to employees than expatriate agreements (Mercer, 2013). One strategy HR departments have been using is to hire employees for foreign subsidiaries from the organization's home country on the basis of agreements which fall under the jurisdiction of the other country and which may provide special rights ("local plus"), and then to have these employees perform work in the foreign subsidiary that in the past would have been carried out by expatriates (which would have been much costlier to the organization). This strategy has also been used by many not-for-profit organizations, even well-renowned ones. The German Education and Science Workers' Union has warned that this has been leading to the creation of a two-tier hierarchy among mobile employees at foreign schools - a situation which will be exacerbated by employing cheap teachers and which in many cases has already had negative effects on the work climate (GEW, 2009). Similar trends have been observed for other not-for-profit organizations, such as the Goethe Institute, and a number of political foundations (Adick et al., 2014; Maletzky \& Weiler, 2013).

When it comes to existing rights and the functioning of bodies of collective labor regulation in Germany (works councils, trade unions, representative committees of executive employees, local groups of the Association of Employed Academics and Executives in the Chemical Industry, union workplace representative groups), transnationally mobile employees from other countries, such as inpatriates, pose special challenges. These employee groups usually have little or no information about issues of collective interest representation, and since they stay only for a short time, they have little interest in such matters, not least because working, employment and participation conditions that are perceived as fair are increasingly assessed on the basis of transnational-justice and social-inequality considerations (Pielage et al., 2012). For example, inpatriates from a poorer country who are sent to Germany on short assignments (of up to one year) perceive their situation as privileged compared with their situation in their country of origin, and while they may feel lonely and have trouble getting used to their new surroundings, their situation is by no means serious enough to make them wish for collective labor regulation. Employees who are sent to Germany on short-term assignments compare their situation in Germany with the situation in their country of origin; however, employees who have been in the country longer tend to compare their situation with the general-more privileged-working and living conditions of the employees in Germany. This is the reason many companies and global-assignment policy developers are very critical about sending inpatriates on overlong assignments, and many of those who have been interviewed for research into this issue have emphasized that after a few years these inpatriates are reluctant to return to their country of origin (Adick et al., 2014).

\section{Conclusion}

This contribution proposes that labor mobility should be analyzed integrating perspectives of business studies, sociology of work and of organizations. Based on an overview of the general historical development of the scope of international labor mobility, the article has shown that the forms of transnational labor mobility are becoming increasingly diverse, and that this development poses new challenges for labor regulation, which lead to the formation of multiple spheres of belonging for employees that create areas which are not covered by the provisions of existing labor regulations and result in transnational inequalities. The members of the traditional migrant groups, who stay in their country of arrival permanently, are - at least officially — subject to the labor standards of the country of arrival and are considered to have the same rights as local employees. In practice, however, many potential sources of inequality and discrimination can be observed. The recent EU enlargements, the introduction of new legislation to enable the migration of third-country nationals, the increasing complexity of temporary solutions to issues of labor and residence laws and the asymmetric distribution of information about employee rights caused by the low level of education and poor language skills of certain groups of immigrants all contribute to the creation of opportunity structures that facilitate the misuse and circumvention of 
labor standards, which may have a negative effect on existing standards. In many cases, there are not enough resources available to monitor these standards, and the ethnical segregation of labor markets leads to a separation of life worlds. Other contributing causes include the non-recognition of qualifications, systematic discrimination against migrants in the labor market and the migrants' social capital (Neumann, 2010). However, in all of these cases it is relatively easy to identify the potential sources of inequality and the standards that should be applied, and to demand compliance with those standards.

It is much more difficult to analyze the situation of those engaging in any of the new or previously largely neglected though increasingly important forms of labor mobility that have been developing in connection with transnational social and working spaces. Multiple belonging can increase migrants' scope of opportunities and the amount of resources available to them but, in extreme cases, it can also lead to permanent marginalization in their country of origin and in the countries to which they might be sent on assignments in the future. Another potential problem is that migrants who are relatively privileged compared with the organization's employees in the country of assignment may still be left at a disadvantage on the level of the family, such as when going abroad has a negative effect on the career of the partners who is going with them.

To fully understand this situation, an integrated analysis is needed that considers the complex interplay of interests involved and includes a comprehensive characterization of the transnational environment. An analysis of expatriates, for example, would have to give special consideration to the interests of the increasing number of dual career couples. It is far from standard procedure for organizations to support the partners of assignees in finding employment in the country of assignment or to help assignees achieve a satisfactory work-family balance, which is particularly important for employees on assignments abroad (Hailey, 1996). The general trend towards a rationalization of employee posting also has specific negative effects on assignees' families, such as when employees are sent on short-term or regional distance assignments without due consideration of the effect this might have on the assignees' partner (Adick et al., 2014; Park/Mense-Petermann, 2014).

Foreign employees who are hired under local employment conditions and who are then sent to another country to perform work there that in the past would have been carried out by expatriates also find themselves confronted with specific issues of labor regulation, which can contribute to the creation of a two-tier workforce (Maletzky \& Weiler, 2013) considering that the conditions for foreign assignments are declining for the traditional groups of employees and the negotiating position of employers is strengthened at the employees' expense. The same is true of inpatriates and third-country nationals, who become competitors of local employees if they work under less favorable employment conditions than the local employees and, being used to lower working standards in their country of origin, introduce new acceptance criteria concerning working, employment and participation conditions.

In the last two decades, a variety of different strategies have been developed to strengthen collective labor regulation on the supranational, transnational and global levels. One such strategy is to establish transnational bodies of co-determination in the form of European works councils or world works councils for large international corporations (Hauser-Ditz et al., 2013; Rosenbohm, 2014). Other strategies include supporting the implementation of international minimum standards, such as those defined by ILO, and the negotiation of international framework agreements between international corporations and trade union associations (Cremers et al., 2007; Hessler, 2012; Dehnen, 2014). These and other important strategic approaches to the transnationalization of labor regulation each have their strengths and weaknesses in terms of actor involvement, distribution of powers and chances to succeed. Their actual and potential roles with regard to working, employment and participation relationships can be analyzed appropriately only if they are conceptualized as threads in an emerging transnational network texture of labor regulation. The transnationalization of labor migration and labor mobility is increasing, and it is especially for this reason that those involved in, and those conducting research on, labor regulation must abandon the concept of national containers and face the fact that the social world is in the process of transnationalization.

\section{References}

Adick, C., Maletzky, M., Pries, L., \& Gandlgruber, B. (2014). Cross-Border Staff Mobility: A Comparative Study. Basingstoke: Palgrave Macmillan (in press). https://doi.org/10.1057/9781137404411

AIRINC. (2011). Local Plus-Tips, Tools, and Trends. Cambridge, MA: Associates for International Research. Retrieved from http://www.air-inc.com/assets/pdfs/Local-Plus-Tips-Tools-and-Trends.pdf

Bade, K. J. (2000). Europa in Bewegung: Migration vom späten 18. Jahrhundert bis zur Gegenwart. Munich: Beck. 
Bade, K. J. (2003). Migration in European History. Malden, MA; Oxford, UK; Carlton, Australia: Blackwell. https://doi.org/10.1002/9780470754658

Besserer, F. (2002). Contesting Community: Cultural Struggles of a Mixtec Transnational Community (PhD Thesis). Stanford University, Stanford, CA.

Borjas, G. J. (1989). Economic Theory and International Migration. International Migration Review, 23(3), 457-485. https://doi.org/10.2307/2546424

Brauch, H. G. (1997). Migration von Nordafrika nach Europa. Spektrum der Wissenschaft, 8, 56.

Braudel, F. (1986). Sozialgeschichte des 15-18. Jahrhunderts: Aufbruch zur Weltwirtschaft. Munich: Kindler.

Brewster, C., \& Lee, S. (2006). HRM in not-for-profit international organizations: Different, but also alike. In H. H. Larsen, \& W. Mayrhofer (Eds.), Managing Human Resources in Europe: A Thematic Approach (pp. 131-148). London; New York, NY: Routledge.

Brookfield. (2012a). Global Relocation Trends: 2012 Survey Report. Halifax, Canada: Brookfield Global Relocation Services. Retrieved from http://espritgloballearning.com/wp-content/uploads/2011/03/2012-Brookfield-Global-Relocations-Trends-S urvey.pdf

Brookfield. (2012b). A look inside Local Plus: Strategic Advisor (Vol. 8, No. 79). Halifax, Canada: Brookfield Global Relocation Services. Retrieved from http://www.brookfieldgrs.com/insights_ideas/advisor/articles/Advisor_Sept12.pdf

Brookfield. (2014). Global Relocation Trends 2014. Halifax, Canada: Brookfield Global Relocation Services. Retrieved from http://knowledge.brookfieldgrs.com/2014_GMTS

Castles, S., \& Miller, M. J. (1993). The Age of Migration: International Population Movements in the Modern World. Basingstoke: Macmillan.

Chen, C. C., Choi, J., \& Chi, S. C. (2002). Making Justice Sense of Local—Expatriate Compensation Disparity: Mitigation by Local Referents, Ideological Explanations, and Interpersonal Sensitivity in China-Foreign Joint Ventures. Academy of Management Journal, 45(4), 807-817. https://doi.org/10.2307/3069313

Collinson, S. (1994). Europe and International Migration. London; New York, NY: Pinter Publishers.

Constant, A. F., \& Massey, D. S. (2003). Labor Market Segmentation and the Earnings of German Guestworkers. In IZA Discussion paper series (No. 774). Bonn: Institute for the Study of Labor. Retrieved from http://www.econstor.eu/bitstream/10419/21465/1/dp774.pdf

Cremers, J. (2007). In search of cheap labour in Europe: Working and living conditions of posted workers. In CLR Studies 6. Brussels: European Institute for Construction Labour Research.

Cremers, J., Dølvik, J. E., \& Bosch, G. (2007). Posting of Workers in the Single Market: Attempts to Prevent Social Dumping and Regime Competition in the EU. Industrial Relations Journal, 38(6), 524-541. https://doi.org/10.1111/j.1468-2338.2007.00462.x

Dehnen, V. (2014). Grenzüberschreitende Verhandlungen: Wie Akteursdynamiken und institutionelle Umwelten Internationale Rahmenvereinbarungen beeinflussen. Frankfurt am Main: Campus.

Doyle, M. W. (2004). The challenge of worldwide migration. Journal of International Affairs, 57(2), 1-5.

Eurostat. (2007). Europe in figures: Eurostat yearbook 2006-2007. Luxembourg: Office for Official Publications of the European Communities.

Faist, T. (2000). The Volume and Dynamics of International Migration and Transnational Social Spaces. Oxford: Oxford University Press. https://doi.org/10.1093/acprof:oso/9780198293910.001.0001

FAZ. (2010, November 9). Mehr Entsendungen. In Frankfurter Allgemeine Zeitung. Retrieved from http://www.faz.net/aktuell/beruf-chance/arbeitswelt/ausland-mehr-entsendungen-11068071.html

Fijalkowski, J. (Ed.). (1990). Transnationale Migranten in der Arbeitswelt: Studien zur Ausländerbeschäftigung in der Bundesrepublik und zum internationalen Vergleich. Berlin: Edition Sigma.

Frank, A. G. (1969). Kapitalismus und Unterentwicklung in Lateinamerika. Frankfurt am Main: Europäische Verlagsanstalt. 
GEW. (2009). Sprung in die Ferne: Auslandsschuldienst-Kein Exotenjob. Frankfurt am Main: German Education and Science Workers Union. Retrieved from $\mathrm{http}: / /$ www.gew.de/Sprung_in_die_Ferne_Auslandsschuldienst_kein_Exotenjob.html

Gordon, J. (2005). Suburban Sweatshops: The Fight for Immigrant Rights. Cambridge, MA: Belknap Press of Harvard University Press. https://doi.org/10.4159/9780674037823

Grasmuck, S., \& Pessar, P. B. (1991). Between Two Islands: Dominican International Migration. Berkeley, CA: University of California Press.

Hailey, J. (1996). The expatriate myth: Cross-cultural perceptions of expatriate managers. The International Executive, 38(2), 255-271. https://doi.org/10.1002/tie.5060380206

Harbach, H. (1976). Internationale Schichtung und Arbeitsmigration. Reinbek bei Hamburg: Rowohlt.

Harvey, M., Novicevic, M. M., Buckley, M. R., \& Fung, H. (2005). Reducing inpatriate managers, Liability of Foreignness by addressing stigmatization and stereotype threats. Journal of World Business, 40(3), 267-280. https://doi.org/10.1016/j.jwb.2005.05.004

Hauser-Ditz, A., Hertwig, M., Mählmeyer, V., \& Rampeltshammer, L. (2013). Transnationalisierung der Automobilindustrie als Herausforderung für Europäische Betriebsräte. In M. Maletzky, M. Seeligera, \& M. Wannöffel (Eds.), Arbeit, Organisation und Mobilität: Eine grenzüberschreitende Perspektive (pp. 190-228). Frankfurt am Main: Campus.

Hessler, S. (2012). Arbeitnehmerrechte weltweit stärken? Die Umsetzung der Internationalen Rahmenvereinbarungen in Mexiko. Frankfurt am Main: Campus.

Hillmann, F., \& Rudolph, H. (1997). S(Z)eitenwechsel-Internationale Mobilität westlicher Hochqualifizierter am Beispiel Polen. Soziale Welt, special issue 12, 245-263.

Hoffmann-Nowotny, H. J. (1970). Migration: Ein Beitrag zu einer soziologischen Erklärung. Stuttgart: Enke.

Holmes, C. (1996). Migration in European History (Vol. I and II). Cheltenham, UK; Brookfield, VT: Edward Elgar.

International Organization for Migration. (2005). World Migration Report 2005: Costs and Benefits of International Migration. Geneva: International Organization for Migration.

International Organization for Migration. (2013). World Migration Report 2013: Migrant Well-Being and Development. Geneva: International Organization for Migration.

Internationale, H. (2014). Auslandsentsendung von Arbeitnehmern. Berlin: The Chamber of Commerce and Industry of Berlin. Retrieved from http://www.ihk-berlin.de/linkableblob/bihk24/recht_und_steuern/downloads/816106/.22./data/Auslandsents endung-data.pdf

Kerr, C. (1954). The Balkanization of Labor Markets. In E. W. Bakke, P. M. Hauser, G. L. Palmer, C. A. Myers, D. Yoder, C. Kerr, \& P. Webbink (Eds.), Labor Mobility and Economic Opportunity: Essays (pp. 92-110). Cambridge, MA: Technology Press of the Massachusetts Institute of Technology; New York, NY: Wiley.

Kesselring, S. (2012). Betriebliche Mobilitätsregime: Zur sozio-geografischen Strukturierung mobiler Arbeit. Zeitschrift für Soziologie, 41(2), 83-100. https://doi.org/10.1515/zfsoz-2012-0203

Kogan, I. (2011). New Immigrants - Old Disadvantage Patterns? Labour Market Integration of Recent Immigrants into Germany. International Migration, 49(1), 91-117. https://doi.org/10.1111/j.1468-2435.2010.00609.x

Konopaske, R., \& Werner, S. (2002). Equity in non-North American contexts: Adapting equity theory to the new global business environment. Human Resource Management Review, 12(3), 405-418. https://doi.org/10.1016/S1053-4822(02)00067-0

KPMG. (2010). Global Assignment Policies and Practices: Survey 2010. In Amstelveen: KPMG. Retrieved from http://www.kpmg.com/ZA/en/IssuesAndInsights/ArticlesPublications/Tax-and-Legal-Publications/Docume nts/GAPP-Survey-2010.pdf

Kritz, M. M., Lim, L. L., \& Zlotnik, H. (Eds.). (1992). International Migration Systems: A Global Approach. Oxford, UK: Clarendon Press; New York, NY: Oxford University Press.

Kuhn, P. A. (1997). The Homeland: Thinking about the History of Chinese Overseas. Canberra: Australian National University. 
Kupka, B., \& Cathro, V. (2007). Desperate housewives-Social and professional isolation of German expatriated spouses. The International Journal of Human Resource Management, 18(6), 951-968. https://doi.org/10.1080/09585190701320908

Lewis, G. J. (1982). Human Migration: A Geographical Perspective. New York, NY: St. Martin's Press.

Lillie, N. (2012). Subcontracting, Posted Migrants and Labour Market Segmentation in Finland. British Journal of Industrial Relations, 50(1), 148-167. https://doi.org/10.1111/j.1467-8543.2011.00859.x

Lutz, H., \& Schwalgin, S. (2006). Vom Weltmarkt in den Privathaushalt: Die neuen Dienstmädchen im Zeitalter der Globalisierung. Opladen: Budrich.

Maletzky, M., \& Weiler, A. (2013). Von grenzüberschreitenden Intrapreneuren und abgesicherten Abenteurern-Die Arbeits-und Entsendesituation von international mobilen Mitarbeitern in regierungsnahen deutschen Non-Profit-Organisationen. Arbeit: Zeitschrift für Arbeitsforschung, Arbeitsgestaltung, Arbeitspolitik, 22(4), 287-301. https://doi.org/10.1515/arbeit-2013-0405

Massey, D. S., Arango, J., Hugo, G., Kouaouci, A., Pellegrino, A., \& Taylor, J. E. (1998). Worlds in Motion: Understanding International Migration at the End of the Millennium. Oxford, UK; New York, NY: Oxford University Press.

Mercer. (2011). Compensating Locally-Hired Foreigners/Expats. New York, NY: Mercer. Retrieved from http://www.imercer.com/uploads/Asia/pdfs/2011-nov-sg-trs-expats.pdf

Mercer. (2013). Auslandsentsendungen nehmen zu: Aktuelle Mercer-Studie. Vienna: Mercer. Retrieved from http://www.mercer-marsh-benefits.com/press-releases/Auslandsentsendungen-nehmen-zu

Moya, J. C. (2007). Domestic Service in a Global Perspective: Gender, Migration, and Ethnic Niches'. Journal of Ethnic and Migration Studies, 33(4), 559-579. https://doi.org/10.1080/13691830701265420

Neumann, S. (2010). Negativ wahrgenommene und klassifizierte Differenz: Zu Nichtanerkennungs-, Missachtungs-und Diskriminierungserfahrungen von BildungsinländerInnen in Kanada und Deutschland. In A. M. Nohl, K. Schittenhelm, O. Schmidtke, \& A. Weiß (Eds.), Kulturelles Kapital in der Migration: Hochqualifizierte Einwanderer und Einwanderinnen auf dem Arbeitsmarkt (pp. 211-223). Wiesbaden: VS Verlag für Sozialwissenschaften. https://doi.org/10.1007/978-3-531-91936-2_14

Nohl, A. M., Ofner, U. S., \& Thomsen, S. (2010b). Hochqualifizierte BildungsausländerInnen in Deutschland: Arbeitsmarkterfahrungen unter den Bedingungen formaler Gleichberechtigung. In A. M. Nohl, K. Schittenhelm, O. Schmidtke, \& A. Weiß (Eds.), Kulturelles Kapital in der Migration: Hochqualifizierte Einwanderer und Einwanderinnen auf dem Arbeitsmarkt (pp. 67-82). Wiesbaden: VS Verlag für Sozialwissenschaften. https://doi.org/10.1007/978-3-531-91936-2_4

Nohl, A. M., Schnittenhelm, K., Schmidtke, O., \& Weiß, A. (2010a). Zur Einführung: Migration, kulturelles Kapital und Statuspassagen in den Arbeitsmarkt. In A. M. Nohl, K. Schittenhelm, O. Schmidtke, \& A. Weiß (Eds.), Kulturelles Kapital in der Migration: Hochqualifizierte Einwanderer und Einwanderinnen auf dem Arbeitsmarkt (pp. 9-35). Wiesbaden: VS Verlag für Sozialwissenschaften. https://doi.org/10.1007/978-3-531-91936-2_1

Pallaske, C. (Ed). (2001). Die Migration von Polen nach Deutschland: Zu Geschichte und Gegenwart eines europäischen Migrationssystems. Baden-Baden: Nomos.

Park, K., \& Mense-Petermann, U. (2014). Managing Across Borders: Global Integration and Knowledge

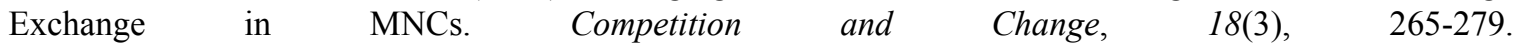
https://doi.org/10.1179/1024529414Z.00000000060

Pielage, P., Pries, L., \& Schultze, G. (Eds.). (2012). Soziale Ungleichheit in der Einwanderungsgesellschaft: Kategorien, Konzepte, Einflussfaktoren: Dokumentation einer gemeinsamen Tagung der Sektion "Migration und ethnische Minderheiten" (MueM) der Deutschen Gesellschaft für Soziologie (DGS) und des Gesprächskreises "Migration und Integration" der Friedrich-Ebert-Stiftung (FES). Bonn: Friedrich Ebert Stiftung.

Piore, M. J. (1979). Birds of Passage: Migrant Labor in Industrial Societies. Cambridge, UK; New York, NY: Cambridge University Press. https://doi.org/10.1017/CBO9780511572210

Pries, L. (Ed.). (2001). New Transnational Social Spaces: International Migration and Transnational Companies in the Early Twenty-First Century. London; New York, NY: Routledge. 
Pries, L. (Ed.). (2008). Rethinking Transnationalism. The Meso-link of organisations. London; New Yoek, NY: Routledge.

Pries, L., \& Seeliger, M. (2013). Work and Employment Relations in a Globalized World: The Emerging Texture of Transnational Labour Regulation. Global Labour Journal, 4(1), 26-47. https://doi.org/10.15173/glj.v4i1.1127

Ravenstein, E. G. (1972). Die Gesetze der Wanderung I und II. In G. Széll (Ed.), Regionale Mobilität: 11 Aufsätze (pp. 41-94). Munich: Nymphenburger Verlagshandlung.

Rerrich, M. S. (2006). Die ganze Welt zu Hause: Cosmobile Putzfrauen in privaten Haushalten. Hamburg: Hamburger Edition.

Reskin, B. F. (1991). Labor Market as Queues: A Structural Approach to Changing Occupational Sex Composition. In D. B. Grusky (Ed.), Social Stratification: Class, Race, and Gender in Sociological Perspective (pp. 718-733). Boulder, CO: Westview Press.

Reynolds, L. G. (1949). Labor Economics and Labor Relations. New York, NY: Prentice-Hall.

Rosenbohm, S. (2014). Verhandelte Mitbestimmung: Die Arbeitnehmerbeteiligung in der Europäischen Aktiengesellschaft. Frankfurt am Main: Campus (in press).

Salustowicz, P. (2009). Internationale Soziale Arbeit zwischen Kolonialisierung, Ethnisierung und Transnationalisierung. In L. Wagner, \& R. Lutz (Eds.), Internationale Perspektiven Sozialer Arbeit: Dimensionen-Themen-Organisationen (2nd ed., pp. 55-72). Wiesbaden: VS Verlag für Sozialwissenschaften. https://doi.org/10.1007/978-3-531-91760-3_4

Sassen, S. (1988). The Mobility of Capital and Labour: A Study in International Investment and Labor Flow. Cambridge: Cambridge University Press. https://doi.org/10.1017/CBO9780511598296

Schittenhelm, K., \& Hatzidimitriadou, E. (2010). Sozialräumliche Koordinaten beruflicher Orientierung: Hochqualifizierte der zweiten Generation in Deutschland und Großbritannien. In A. M. Nohl, K. Schittenhelm, O. Schmidtke, \& A. Weiß (Eds.), Kulturelles Kapital in der Migration: Hochqualifizierte Einwanderer und Einwanderinnen auf dem Arbeitsmarkt (pp. 301-314). Wiesbaden: VS Verlag für Sozialwissenschaften. https://doi.org/10.1007/978-3-531-91936-2_21

Schmidtke, O. (2010). Ethnisches kulturelles Kapital in der Arbeitsmarktintegration: Zwischen ethnischer Nischenökonomie und Übergang in den allgemeinen Arbeitsmarkt. In A. M. Nohl, K. Schittenhelm, O. Schmidtke, \& A. Weiß (Eds.), Kulturelles Kapital in der Migration: Hochqualifizierte Einwanderer und Einwanderinnen auf dem Arbeitsmarkt (pp. 247-259). Wiesbaden: VS Verlag für Sozialwissenschaften. https://doi.org/10.1007/978-3-531-91936-2_17

Schmierl, K. (2011). Internationaler Personaleinsatz im Mittelstand: Wandel der Arbeit jenseits von Arbeitsregulierung und Normierung. Arbeits- und Industriesoziologische Studien, 4(1), 33-47.

Schönwälder, K., Vogel, D., \& Sciortino, G. (2004). Migration und Illegalität in Deutschland: AKI-Forschungsbilanz 1. Berlin: Social Science Research Center. Retrieved from http://www.proasyl.de/texte/mappe/2005/97/24.pdf

Sengenberger, W. (1987). Struktur und Funktionsweise von Arbeitsmärkten: Die Bundesrepublik Deutschland im internationalen Vergleich. Frankfurt am Main; New York, NY: Campus.

Shaffer, M. A., Harrison, D. A., Gilley, K. M., \& Luk, D. M. (2001). Struggling for balance amid turbulence on international assignments: Work-family conflict, support and commitment. Journal of Management, 27(1), 99-121. https://doi.org/10.1177/014920630102700106

Shaw, J. (2003). Who Built the Pyramids? Harvard Magazine, 105(7/8), 42-49.

Shinozaki, K. (2013). Irregular Migrant Citizenship: Exploring a Conceptual Horizon of Global Care Chains through Domestic Workers' Negotiation over Social and Economic Rights. In M. Maletzky, M. Seeliger, \& M. Wannöffel (Eds.), Arbeit, Organisation und Mobilität: Eine grenzüberschreitende Perspektive (pp. 109-131). Frankfurt am Main: Campus.

Shortland, S., \& Cummins, S. (2007). Work-Life Balance: Expatriates Reflect the International Dimension. Global Business and Organizational Excellence, 26(6), 28-42. https://doi.org/10.1002/joe.20172

Smith, R. (2005). Mexican New York: Transnational Lives of New Immigrants. Berkeley, CA: University of California Press. 
Solimano, A. (2004). Globalization, history and international migration: A view from Latin America. In Working Paper (No. 37). Geneva: International Labour Office.

Stalker, P. (2000). Workers without Frontiers: The Impact of Globalisation on International Migration. Boulder, CO: Lynne Rienner Publishers; Geneva: International Labour Office.

Staples, R., Trinczek, R., \& Whittall, M. (2013). "PostedWorkers": Zwischen Regulierung und Invisibilisierung. Arbeit, 22(4), 271-286.

Stuckey, B., \& Fay, M. (1980). Produktion, Reproduktion und Zerstörung billiger Arbeitskraft: Ländliche Subsistenz, Migration und Urbanisierung. In M. Fay, E. Feder, A. G. Frank, F. Fröbel, J. Heinrichs, O. Kreye, A. M. Münster, \& B. Stuckey (Eds.), Strukturver änd erungen in der kapitalistischen Weltwirtschaft (pp. 126-168). Frankfurt am Main: Suhrkamp.

Torpey, J. (2000). The Invention of the Passport: Surveillance, Citizenship, and the State. Cambridge, UK; New York, NY: Cambridge University Press.

Treibel, A. (1990). Migration in modernen Gesellschaften: Soziale Folgen von Einwanderung und Gastarbeit. Weinheim; Munich: Juventa.

Union of International Organizations. (2012). Yearbook of International Organizations 2011/2012, Volume 5: Statistics, Visualizations and Patterns. Retrieved from http://www.brill.com/downloads/2011_YBIO5_Historical_overview_of_number_of_intl_organizations_by type.pdf

United Nations Development Programme. (2009). Human Development Report 2009: Overcoming barriers: Human mobility and development. New York, NY: United Nations Development Programme.

United Nations High Commission for Refugees. (2012). UNHCR Statistical Yearbook 2011. Geneva: United Nations High Commissioner for Refugees.

Verband Deutsches Reisemanagemente e.V. (2014). Leichtes Wachstum im Geschäftsreisemarkt. Retrieved from https://www.vdr-service.de/service/presse/news/leichtes-wachstum-im-geschaeftsreisemarkt/

Verwiebe, R. (2004). Transnationale Mobilität innerhalb Europas: Eine Studie zu den sozialstrukturellen Effekten der Europäisierung. Berlin: Edition Sigma.

Wallerstein, I. M. (1974). The Modern World System I: Capitalist Agriculture and the Origins of the European World-Economy in the Sixteenth Century. New York, NY: Academic Press.

Wimmer, A., \& Glick, S. N. (2002). Methodological nationalism and beyond: Nation-state building, migration and the social sciences. Global Networks, 2(4), 301-334. https://doi.org/10.1111/1471-0374.00043

\section{Notes}

Note 1 . While the situation has probably improved a little since the study was conducted, there is still little research on the life worlds of the female partners of employees who are sent abroad and on the views of gender roles in German companies.

Note 2. "MigrAr" is short for "Migration und Arbeit" ("Migration and Labour").

Note 3. For example, the Posting-of-Workers Directive (Directive 96/71/EC) provides regulations on maximum work periods and minimum rest periods; minimum paid annual holidays; the minimum rates of pay; the conditions of hiring-out of workers; health, safety and hygiene at work; measures to protect pregnant women or women who have recently given birth; equality of treatment between men and women and other provisions on non-discrimination.

\section{Copyrights}

Copyright for this article is retained by the author(s), with first publication rights granted to the journal.

This is an open-access article distributed under the terms and conditions of the Creative Commons Attribution license (http://creativecommons.org/licenses/by/4.0/). 